\title{
Comparative assessment of family planning knowledge and attitude of men in urban and rural areas of Anambra state, South-East of Nigeria
}

\author{
Chigozie O. Ifeadike ${ }^{1 *}$, Precious N. Eze ${ }^{1}$, Uchenna M. Ugwoke ${ }^{1}$ and Godswill A. Nnaji
}

*Correspondence: gozifeadike@yahoo.com

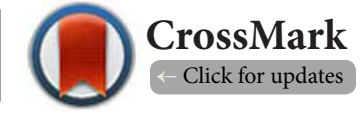

'Department of Community Medicine, Nnamdi Azikiwe University Teaching Hospital, Nnewi, Anambra State, Nigeria.

${ }^{2}$ Department of Family Medicine, Nnamdi Azikiwe University Teaching Hospital, Nnewi, Anambra State, Nigeria.

\begin{abstract}
Background: Men's involvement in family planning is being seen as important in the enlightenment campaign for family planning especially in the rural areas.

Objectives: This study compared family planning knowledge and attitude among men in urban and rural areas of Anambra state, South-East Nigeria.

Methods: Men aged 19-61 who were sexually active and in a current sexual relationship with women aged 15-49 regardless of marital status were studied using a structured questionnaire. Data was analysed using inferential statistical techniques, i.e., Chi-square and Fishers exact tests. The statistical software used was SPSS version 16 and $p$-value at $<0.05$ for significance.

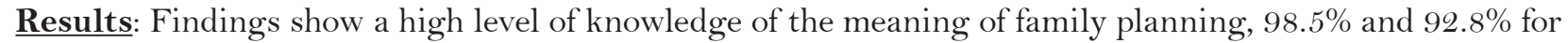
urban and rural respondents, respectively. The difference is statistically significant $(\mathrm{OR}=4.952,95 \% \mathrm{CI}=1.39-$ $17.51 \mathrm{p}<0.05)$. Similarly, negative response to all artificial family planning cause infertility, $61.9 \%$ and $49.5 \%$, for urban and rural population, respectively $(\mathrm{OR}=1.66,95 \% \mathrm{CI}=1.10-2.48, \mathrm{p}<0.05)$; family planning is necessary for good health of the family, $91.8 \%$ and $81.4 \%$ for urban and rural population respectively $(\mathrm{OR}=2.5$, $95 \% \mathrm{CI}=1.35-4.74 ; \mathrm{p}<0.05$ ). Analysis of attitude towards family planning is positive as $96.4 \%$ and $76.3 \%$ urban and rural respondents, respectively believe that using contraceptive doesn't mean that one is wayward $\left(\mathrm{X}^{2}=36.6, \mathrm{Df}=2\right.$, P-value=0.0; $\left.\mathrm{p}<0.05\right)$; birth control is not a sin, $75.3 \%$ and $59.3 \%$ for urban and rural populations, respectively $\left(\mathrm{X}^{2}=12.24, \mathrm{Df}=2, \mathrm{P}\right.$-value $\left.=0.0, \mathrm{p}<0.05\right)$; and family size has effect on well-being of the family, $85.6 \%$ and $69.6 \%$ for urban and rural populations, respectively $\left(\mathrm{X}^{2}=14.51, \mathrm{Df}=2\right.$, $\mathrm{P}-\mathrm{value}=0.0$; $\mathrm{p}<0.05)$.
\end{abstract}

Conclusion: Although, there is a high level of knowledge and positive attitude to family planning among men in both urban and rural populations studied, the urban men have a significantly higher percentage of knowledge and positive attitude to family planning than their rural counterpart.

Keywords: Family planning, male involvement, knowledge, attitude

\section{Introduction}

The World Health Organization defined family planning as the act which allows individuals and couples to anticipate and attain their desired number of children and the spacing and timing of their births. It is achieved through use of contraceptive methods and the treatment of involuntary infertility [1]. A woman's ability to space and limit her pregnancies has a direct impact on her health and well -being as well as on the outcome of each pregnancy [1].

Family planning is regarded as a vital and integral component of Primary Health Care which aims at promoting responsible parenthood, controlling population and improving quality of life of the people [2]. One of the most serious problems developing countries still have to solve is their rapid and uncontrolled 
Ifeadike et al. Research Journal of Women's Health 2015,

increase in population [3]. Many developing societies are characterized by rapid population growth due to high fertility and declining mortality in Sub-Saharan African. The rate of population growth is one of the highest in the world, with an average growth rate of $2.53 \%$ [4].

The world's population has been rising steadily, reaching above 7 billion with more than $71 \%$ living in developing countries [5] and current United Nations' projections showed a continued increase in population in the near future, with the global population expected to reach between 8.3 and 10.9 billion by $2050[6,7]$. Nearly all $(97 \%)$ of the 2.3 billion projected increase will be in the less developed regions, with nearly half in Africa [8]. Average world population change is estimated at around 80 million per year with a growth rate of around $1.14 \%$ per year [9] and $2.53 \%$ in Sub-Saharan Africa [4]. Nigeria's population growth rate of $2.553 \%$ per annum results from a surplus of births over deaths giving a population of over 167 million which is said to be too large for comfort [10] and is expected to surpass the United States population in 2045 to become the third most populous country in the world, starting to rival China by the end of the century with almost 1 billion people in 2100 [9]. With a large unmet need for family planning and a low contraceptive prevalence rate, Nigerians are still having more children than planned and at a shorter than desired birth intervals [11].

It is well documented that men's general knowledge and attitudes concerning the ideal family size, gender preference of children, ideal spacing between childbirth, and contraceptive method use greatly influence women's preferences and opinions [12]. Fertility and family planning research and programs have ignored men's roles in the past focusing on women's behavior, [12] and services are traditionally presented within the context of maternal and child health [13]. African men play important roles in the decisions about family life including fertility and family planning [14].

Since the 1994 International Conference on Population and Development (ICPD) and the 1995 United Nations World Conference on women, interest in men's involvement in reproductive health has increased $[12,14]$. Research on the determinants of fertility in Sub-Saharan African and in programs designed to increase contraceptive use among African Population shows increasing attention is being paid to the contraceptive knowledge, attitudes and practices of African men [15]. The shift in focus on men's reproductive health was influenced by the 1994 Cairo (ICPD) Action Plan to promote gender equality and equity, empower women and improve family health in society [16].

Women depend on men to take decisions on contraception, and more so in the rural areas where traditional settings still exist. There appears to be a difference between the knowledge and attitude of contraception between urban and rural male dwellers.

This study aims at comparing the level of knowledge and attitude of family planning among men in two (urban and rural)
LGAs of Anambra state of Nigeria. Specifically, the objectives of this study is to compare the knowledge and attitude of Family Planning among men in two LGAs, Onitsha North (urban) and Ayamelum LGA (rural), both in Anambra state, Nigeria.

\section{Materials and methods}

This is a descriptive, comparative cross-sectional study conducted from January $8^{\text {th }}$ to February $7^{\text {th }} 2014$ in Onitsha North LGA (urban LGA) and Ayamelum LGA (rural LGA) both in Anambra state, Southeast of Nigeria. The population of Onitsha North LGA is 205,726, while that of Ayamelum LGA is $145,835[17,18]$. The state population is 4.2 million and mainly inhabited by lgbo speaking people who are mostly Christians and most members of the population are farmers, artisans and civil servants. The study population was 388 males (194 in each LGA) aged 19-61 years of age who were sexually active and in current sexual relationship with women aged 15-49 years regardless of their marital status but were resident in the areas of study.

Multistage sampling technique was used to select 388 men from 388 households.

Stage 1: one urban and one rural LGAs were selected through simple random sampling.

Stage 2: two wards were selected from the list of wards in each selected LGA through random sampling. Stage 3: two streets (from a frame of 8 streets) and 2 villages (from a frame of 6 villages) were selected randomly from urban and rural wards respectively. Stage 4: 194 households (from a frame of 473 households) and another 194 households (from a frame of 451 households) were selected through systematic sampling from urban and rural wards respectively i.e., a total of 388 households from 924 households with PHC house marking (used for vaccination). The first eligible male encountered in each household was recruited for the study.

Data was collected with the aid of two research assistants using self-administered questionnaire for the educated males and interviewer-administered for the non-educated respondents. The questionnaire was pre-tested for appropriateness and clarity on men similar in characteristics to the population studied but in different LGAs of the state. It has sections that explore the socio-demographic characteristics of the respondents, knowledge and attitude of family planning and also on factors influencing their decision on the practice of family planning. The section on knowledge and attitude contain five questions each with statements requiring choice of answers in three categories, i.e., agree, disagree, and does not know.

Data was entered and analysed using Statistical Package for Social Sciences (SPSS) version 16. Frequencies and percentages were presented as tables. Statistically significant differences $(P<0.05)$ were identified using a chi-square test, Fisher's exact test and Odds Ratio analysis.

Ethical approval for the study was obtained from the Ethics Committee of Nnamdi Azikiwe University Teaching Hospital, Nnewi. Informed consent was obtained from all respondents. 
Ifeadike et al. Research Journal of Women's Health 2015,

\section{Results}

A total of 388 males, 194 from each of the study areas were interviewed. The socio-demographic characteristics of these men are presented in Table 1. Enrollees were aged 19-61 years with a mean age of $36 \pm 10.2$ years and $39.9 \pm 10.6$ years for the urban and rural areas respectively and most were married. The modal age for both rural and urban respondents was

Table 1. Socio-demographic distribution of the respondents $(\mathrm{N}=388)$.

\begin{tabular}{lllllll}
\hline Variable & $\begin{array}{c}\text { Urban } \\
(\mathbf{n}=\mathbf{1 9 4}) \\
\mathbf{N}(\%)\end{array}$ & $\begin{array}{l}\text { Rural } \\
(\mathbf{n = 1 9 4 )} \\
\mathbf{N}(\%)\end{array}$ & Total & $\mathbf{X}^{2}$ & DF & P-value \\
\multicolumn{7}{l}{ Age group } \\
(years) \\
\hline $20-29$ & $48(24.2)$ & $30(15.2)$ & 78 & 11.238 & 4 & $0.02^{*}$ \\
$30-39$ & $68(34.3)$ & $62(31.3)$ & 130 & -- & -- & -- \\
$40-49$ & $55(27.8)$ & $59(29.8)$ & 114 & -- & -- & -- \\
$50-59$ & $20(0.1)$ & $40(20.2)$ & 60 & -- & -- & -- \\
$>60$ & $3(1.5)$ & $3(1.5)$ & 6 & -- & -- & -- \\
\hline
\end{tabular}

\begin{tabular}{lllllll}
\hline \multicolumn{1}{l}{ Occupation } & & & & & & \\
\hline Apprentice & $16(8.2)$ & $7(3.6)$ & 23 & 135.567 & 6 & $.0^{*}$ \\
Civil & $34(17.5)$ & $11(5.7)$ & 45 & $\left(176.067^{\text {ă}}\right)$ & -- & -- \\
servant & & & & & & \\
Laborer & $15(7.8)$ & $38(19.6)$ & 53 & -- & -- & -- \\
Student & $34(17.5)$ & $20(10.3)$ & 54 & -- & -- & -- \\
Teacher & $17(8.8)$ & $8(4.1)$ & 25 & -- & -- & -- \\
Trader & $78(40.2)$ & $29(14.9)$ & 107 & -- & -- & -- \\
Farmer & $0(0.0)$ & $81(41.8)$ & 81 & -- & -- & -- \\
\hline
\end{tabular}

\begin{tabular}{lllllll}
\hline Religion & & & & & & \\
\hline Anglican & $52(26.8)$ & $47(24.2)$ & 99 & 38.4109 & 4 & $0^{*}$ \\
Catholic & $99(51.0)$ & $94(48.5)$ & 193 & -- & -- & -- \\
Others & $8(4.2)$ & $15(7.7)$ & 23 & -- & -- & -- \\
Pentecostal & $34(17.5)$ & $11(5.7)$ & 45 & -- & -- & -- \\
Traditional & $1(0.5)$ & $27(13.9)$ & 28 & -- & -- & -- \\
\hline
\end{tabular}

\begin{tabular}{lllllll}
\hline \multicolumn{2}{l}{ Marital status } & & & & & \\
\hline $\begin{array}{l}\text { Separated/ } \\
\text { Divorced }\end{array}$ & $2(1.0)$ & $0(0)$ & 2 & 8.6406 & 3 & $0.03^{* *}$ \\
Married & $\begin{array}{l}119 \\
(61.3)\end{array}$ & $140(72.2)$ & 259 & $\left(9.641^{\mathrm{a}}\right)$ & -- & 0.02 \\
& & & & & \\
Single & $68(35.1)$ & $46(23.7)$ & 114 & -- & -- & -- \\
Widowed & $5(2.6)$ & $8(4.1)$ & 13 & -- & -- & -- \\
\hline Educational level & & & & & \\
\hline $\begin{array}{l}\text { No formal } \\
\text { education }\end{array}$ & $1(0.5)$ & $38(19.6)$ & 39 & 81.378 & 3 & $0^{*}$ \\
Primary & $25(12.9)$ & $52(26.8)$ & 77 & -- & -- & -- \\
Secondary & $71(36.6)$ & $75(38.7)$ & 146 & -- & -- & -- \\
Tertiary & $97(50.0)$ & $29(14.9)$ & 126 & -- & -- & -- \\
\hline
\end{tabular}

(a) Correction for cells with zero

${ }^{\star}$ Chi-square test holds and were significant $(\mathrm{p}<0.05)$

**Yates' Chi-square $=7.085$. Yates' $p$-value $=0.069(p>0.05)$
30 to 39 age group. The proportion of younger age groups (20-29 and 30-39 years) among the urban participants (24.2\% and $34.3 \%$, respectively) compared to the rural participants (15.6\% and $31.3 \%$, respectively). Similarly, the proportion of older participants (40-49 and 50-59 years groups) are greater among the rural than urban people $(29.8 \%$ and $20.2 \%$ compared to $27.8 \%$ and $0.1 \%$, respectively. These difference in their age distribution is statistically significant $X^{2}=11.24, D f=4$, P-value $=0.02:(p<0.05)$.

The majority of the rural participants were farmers (41.8\%) followed by laborers (19.6\%) compared to their urban counterparts $(0.0 \%$ and $7.8 \%$, respectively), while Traders constitutes the majority in the urban participants (40.2\%). These difference is statistically significant $X^{2}=176.067, D f=6$, $P$-value $=0(p<0.05)$.

The majority of the respondents in both urban and rural participants were Christians ( $95 \%$ and $86.1 \%$, respectively), of which $51.0 \%$ and $48.5 \%$, respectively were Catholics. The difference was statistically significant $X^{2}=38.41, D f=4, P$-value $=0.0(p<0.05)$.

A greater proportion of the participants in the rural area (72.2\%) was married compared to figure in urban area (61.3\%). There were more single participants in the urban area (35.1\%) than in the rural area (23.7\%). The difference was statistically significant $X^{2}=9.64, D f=3, P$-value $=0.02(p<0.0 .5)$.

Fifty percent of participants in the urban group attended tertiary education compared to only $14.9 \%$ in the rural groups. Also, a higher percentage (19.6\%) of rural participants had no formal education compared to the urban group (0.5\%). The difference was statistically significant $X^{2}=81.37, D f=3$, $P$-value $=0.00(p<0.05)$.

Almost all the respondents in both populations, 191 (98.5\%) for urban and $180(92.8 \%)$ for the rural know the correct meaning of family planning (see Table 2). The difference is statistically significant $X^{2}=7.44, D f=1, P$-value $=0.01(p<0.05)$ while 192 (99.0\%) and 191 (98.5\%) respectively for urban and rural know there are two main types of family planning methods. However the difference was not statistically significant ( $p>0.05$ ). Also, 120 (61.9\%) of urban and $96(49.5 \%)$ of rural respondents disagreed with the fact that all artificial methods of family planning cause permanent sterility (statistically significant $\mathrm{X}^{2}=6.016, \mathrm{Df}=1, \mathrm{P}$-value $\left.=0.01 ; \mathrm{p}<0.05\right)$, while $178(91.8 \%)$ of urban respondents and $158(81.4 \%)$ agree that family planning is necessary for the good health of the family. This difference is statistically significant $X^{2}=8.88, D f=1, P$-value $=0.0(p<0.05)$. Also, 92 (47.4\%) of urban respondents and 96 (49.5\%) of rural respondents knew that family planning is not just about preventing pregnancy only (not statistically significant $p>0.05$ ).

Table 3 shows that 187 or $96.4 \%$ of urban participants disagree with the statement that only wayward women use contraceptives compared with 148 or $76.3 \%$ in the rural group. The difference is statistically significant $\left(X^{2}=36.6, D f=2, P<0.05\right)$.

A greater percentage of urban participants 146 or $75.3 \%$ disagree with the statement that birth control is a sin compared with 115 or $59.3 \%$ in the rural group.The difference is 
Ifeadike et al. Research Journal of Women's Health 2015,

http://www.hoajonline.com/journals/pdf/2054-9865-2-3.pdf

doi: $10.7243 / 2054-9865-2-3$

Table 2. Respondents knowledge of family planning.

\begin{tabular}{|c|c|c|c|c|c|c|}
\hline \multirow[t]{2}{*}{ Statement } & \multicolumn{2}{|c|}{ Urban $(n=194)$} & \multicolumn{2}{|c|}{ Rural (n=194) } & \multirow[t]{2}{*}{$\mathrm{X}^{2}$} & \multirow[t]{2}{*}{ P-value } \\
\hline & Yes $(\%)$ & No (\%) & Yes $(\%)$ & No $(\%)$ & & \\
\hline $\begin{array}{l}\text { Family planning is a means of controlling and spacing the number of } \\
\text { children born in a family. }\end{array}$ & $191(98.5)$ & $3(1.5)$ & $180(92.8)$ & $14(7.2)$ & 7.444 & $0.01^{*}$ \\
\hline There are natural and artificial methods of family planning. & 192(99.0) & $2(1.0)$ & $191(98.5)$ & $3(1.5)$ & 0.203 & 0.65 \\
\hline All artificial method of family planning cause permanent sterility. & $74(38.1)$ & $120(61.9)$ & $98(50.5)$ & $96(49.5)$ & 6.016 & $0.01^{*}$ \\
\hline Family planning is necessary for the good health of the family. & $178(91.8)$ & $16(8.2)$ & $158(81.4)$ & $36(18.6)$ & 8.883 & $0.00^{*}$ \\
\hline Family planning involves preventing pregnancy only. & $102(52.6)$ & $92(47.4)$ & $98(50.5)$ & $96(49.5)$ & 0.165 & 0.69 \\
\hline
\end{tabular}

*Indicates significant p-value while, Degree of Freedom in each is 1.

Table 3. Respondents' attitude towards family planning.

\begin{tabular}{|c|c|c|c|c|c|c|c|c|}
\hline \multirow[t]{2}{*}{ Statement } & \multicolumn{3}{|c|}{ Urban $(n=194) \mathrm{N}(\%)$} & \multicolumn{3}{|c|}{ Rural (n=194) N(\%) } & \multirow[t]{2}{*}{$\mathrm{X}^{2}$} & \multirow[t]{2}{*}{ P-value } \\
\hline & Agree & Disagree & Not sure & Agree & Disagree & Not sure & & \\
\hline Only wayward women use contraceptives. & $2(1)$ & $187(96.4)$ & $5(2.6)$ & $36(18.6)$ & $148(76.3$ & $10(5.2)$ & 36.6 & $0.0^{*}$ \\
\hline Birth control is a sin & $21(10.8)$ & $146(75.3)$ & $27(13.9)$ & $42(21.6)$ & $115(59.3)$ & $37(19.1)$ & 12.24 & $0.0^{*}$ \\
\hline A man should not count his children. & $13(6.7)$ & $180(92.8)$ & $1(0.5)$ & 23(11.9) & $170(87.6)$ & $1(0.5)$ & 3.06 & 0.21 \\
\hline Birth control is the woman's business. & $17(8.8)$ & $176(90.7)$ & $1(0.5)$ & $17(8.8)$ & $175(90.2)$ & $2(1)$ & 0.336 & 0.84 \\
\hline $\begin{array}{l}\text { Family size does not have effect on the } \\
\text { wellbeing of the family. }\end{array}$ & $24(12.3)$ & $166(85.6)$ & $4(2.1)$ & $53(27.3)$ & $135(69.6)$ & $6(3.1)$ & 14.51 & $0.0^{*}$ \\
\hline
\end{tabular}

*Significant $\mathrm{p}$-values $(\mathrm{p}<0.05)$ Degree of Freedom $=2$ for each response.

statistically significant $\left(X^{2}=12.24, D f=2, P<0.05\right)$. On the statement that a man should not count his children, the negative response from urban (180 or $92.8 \%$ ) and rural groups (170 or $87.6 \%)$ were not statistically significantly different $\left(X^{2}=3.06\right.$, $\mathrm{DF}=2, \mathrm{P}=0.21 ; \mathrm{p}>0.05)$. Similarly, the negative response to the statement that birth control is a woman's business were not statistically significantly different between the two groups $\left(\mathrm{X}^{2}\right.$ $=0.336, \mathrm{Df}=2, \mathrm{P}$-value $=0.84: \mathrm{p}>0.05)$. However, the difference in negative response to the statement that family size does not have effect on the well-being of the family 166 or $85.6 \%$ for urban and 135 or $69.6 \%$ for rural groups was statistically significantly $\left(X^{2}=14.51, D f=2, P=0: p<0.05\right)$.

Table 4 shows that 191 or $98.5 \%$ of urban participants know meaning of family planning compared to 180 or $92.8 \%$ of their rural counterparts. The difference is statistically significant $(\mathrm{OR}=4.952,95 \% \mathrm{C} 1=1.3$ to $17.5, \mathrm{P}$-value $=0.01: \mathrm{p}<0.05)$. There is a higher percentage of participants who know about natural and artificial methods in urban (192 or $99.0 \%$ ) than in rural groups (191 or $98.5 \%$ ). However, the difference is not statistically significant $(\mathrm{OR}=1.508,95 \% \mathrm{Cl}=0.2$ to 9.1 , $\mathrm{P}$-value $=0.5$; $\mathrm{p}>0.05$ ). A higher percentage of urban participants 120 or $61.9 \%$ perceived that all artificial methods of family planning cause permanent infertility compared to 98 or $49.5 \%$ of rural group. The difference is statistically significant ( $O R=1.655,95 \%$ $\mathrm{Cl}=1.105-2.48 ; \mathrm{P}$-value $=0.014)$. Similarly, a higher percentage of urban participants (178 or $91.8 \%$ ) agree that family planning is necessary for good health of the family compared to
158 or $81.4 \%$ or the rural group. The difference is statistically significant $(\mathrm{OR}=2.535,95 \% \mathrm{Cl}=1.354-4.744$, $\mathrm{P}$-value $=0.002$; $\mathrm{p}<0.05$ ). Less than half of the urban participants (92 or $47.4 \%$ ) agree that family planning involves preventing pregnancy only, while a higher figure for rural respondents (96 or 49.5\%) gave the same response.

Table 5 shows that the urban group have a higher percentage of positive attitude (187 or $96.4 \%$ compared to their rural counterpart (148 or $76.3 \%$ ). The difference is statistically significant $(\mathrm{OR}=8.303,95 \% \mathrm{Cl}=3.64-18.92$, $\mathrm{P}$-value $=0.00$; $\mathrm{p}<0.05$ ). Three quarters of the urban group (146 or $75.3 \%$ ) perceive birthcontrol as not a sin compared to 115 or $59.3 \%$ of their rural counterpart.The difference is statistically significant $(\mathrm{OR}=2.089,95 \% \mathrm{Cl}=1.35-3.23$, $\mathrm{P}$-value $=0.00 ; \mathrm{p}<0.00)$. A majority of the urban participants 180 or $92.8 \%$ disagree with the statement that a man should not count his children compared to 170 or $87.6 \%$ of the rural group. This difference is statistically significant $(\mathrm{OR}=1.815,95 \% \mathrm{Cl}=0.909-3.62$, $\mathrm{P}$-value $=0.08 ; \mathrm{p}>0.05)$. Similarly, there was no statistically significant difference between the negative response of the urban $(90.7 \%)$ and the rural groups $(90.2 \%)$ on birth control being a woman's business $(\mathrm{OR}=1.062,95 \% \mathrm{Cl}=0.56-2.09$, $\mathrm{P}$ value $=0.1: p>0.05$ ). A higher percentage of the urban group (166 or $85.6 \%$ ) disagree that the family size does not affect the well being of the family compared to 135 or $69.6 \%$ of the rural group. The difference is statistically significant $(\mathrm{OR}=2.59$, $95 \% \mathrm{Cl}=1.56-4.3$, P-value=0.00; $\mathrm{p}<0.05)$. 
Ifeadike et al. Research Journal of Women's Health 2015,

Table 4. Comparison of correct knowledge of family planning between urban and rural respondents.

\begin{tabular}{|c|c|c|c|c|c|c|c|c|}
\hline \multirow[t]{2}{*}{ Knowledge } & & \multirow{2}{*}{$\begin{array}{l}\text { Urban } \\
(\mathrm{n}=194) \\
\mathrm{N}(\%)\end{array}$} & \multirow{2}{*}{$\begin{array}{l}\text { Rural } \\
(n=194) \\
N(\%)\end{array}$} & \multirow[t]{2}{*}{$\begin{array}{l}\text { Odds } \\
\text { Ratio }\end{array}$} & \multicolumn{2}{|c|}{$\begin{array}{l}95 \% \text { Confidence } \\
\text { interval }\end{array}$} & \multirow[t]{2}{*}{$\begin{array}{l}\text { Chi } \\
\text { square }\end{array}$} & \multirow[t]{2}{*}{ P-value } \\
\hline & & & & & $\begin{array}{l}\text { Lower } \\
\text { limit }\end{array}$ & $\begin{array}{l}\text { Upper } \\
\text { limit }\end{array}$ & & \\
\hline \multirow{2}{*}{$\begin{array}{l}\text { Family planning is a means of controlling and } \\
\text { spacing the number of children born in a family. }\end{array}$} & Yes & 191(98.5) & $180(92.8)$ & 4.952 & 1.3997 & 17.518 & 6.15 & $0.01^{\star}$ \\
\hline & No & $3(1.5)$ & $14(7.2)$ & -- & -- & -- & -- & -- \\
\hline \multirow{2}{*}{$\begin{array}{l}\text { There are natural and artificial methods of family } \\
\text { planning. }\end{array}$} & Yes & 192(99.0) & 191(98.5) & 1.508 & 0.2491 & 9.1257 & 0.02 & 0.5 \\
\hline & No & $2(1.0)$ & $3(1.5)$ & -- & -- & -- & -- & -- \\
\hline \multirow[t]{2}{*}{$\begin{array}{l}\text { All artificial methods of family planning cause } \\
\text { permanent sterility. }\end{array}$} & Yes & $120(61.9)$ & $96(49.5)$ & 1.655 & 1.105 & 2.479 & $6.02(5.52)$ & $\begin{array}{l}0.014^{*} \\
(0.018)\end{array}$ \\
\hline & No & $74(38.1)$ & $98(50.5)$ & -- & -- & -- & -- & -- \\
\hline \multirow{2}{*}{$\begin{array}{l}\text { Family planning is necessary for good health of } \\
\text { the family. }\end{array}$} & Yes & $178(91.8)$ & $158(81.4)$ & 2.535 & 1.3545 & 4.744 & $8.8(8.02)$ & $0.002^{*}$ \\
\hline & No & $16(8.2)$ & $36(18.6)$ & -- & -- & -- & -- & -- \\
\hline \multirow[t]{2}{*}{$\begin{array}{l}\text { Family planning involves preventing pregnancy } \\
\text { only. }\end{array}$} & Yes & $92(47.4)$ & $96(49.5)$ & 0.921 & 0.618 & 1.371 & $0.17(0.09)$ & $\begin{array}{l}0.68 \\
(0.76)\end{array}$ \\
\hline & No & $102(52.6)$ & $98(50.5)$ & -- & -- & -- & -- & -- \\
\hline
\end{tabular}

Note $^{*}$ statistically significant $\left.=\mathrm{p}<0.05\right)$. Yate's correction for Chi square test $\left(\mathrm{X}^{2}\right)$.

Table 5. Comparison of positive attitude to family planning between urban and respondents.

\begin{tabular}{|c|c|c|c|c|c|c|c|c|}
\hline \multirow[t]{2}{*}{ Attitude } & & \multirow{2}{*}{$\begin{array}{l}\text { Urban } \\
(\mathrm{n}=194) \\
\mathrm{N}(\%)\end{array}$} & \multirow{2}{*}{$\begin{array}{l}\text { Rural } \\
(\mathrm{n}=194) \\
\mathrm{N}(\%)\end{array}$} & \multirow[t]{2}{*}{ Odds Ratio } & \multicolumn{2}{|c|}{ 95\% Confidence interval } & \multirow[t]{2}{*}{ Chi square } & \multirow[t]{2}{*}{ P-value } \\
\hline & & & & & Upper limit & Lower limit & & \\
\hline \multirow[t]{2}{*}{ Only wayward women use contraceptives. } & Yes & $7(3.6)$ & $46(23.7)$ & 8.303 & 3.643 & 18.93 & 33.24 & $0.00^{\star}$ \\
\hline & No & $187(96.4)$ & $148(76.3)$ & -- & -- & -- & -- & -- \\
\hline \multirow[t]{2}{*}{ Birth control is a sin. } & Yes & $48(24.7)$ & $79(40.7)$ & 2.089 & 1.354 & 3.23 & 11.25 & $0.00^{*}$ \\
\hline & No & $146(75.3)$ & $115(59.3)$ & -- & -- & -- & $(10.5)$ & $(0.0)$ \\
\hline \multirow[t]{2}{*}{ A man should not count his children. } & Yes & $14(7.2)$ & $24(12.4)$ & 1.815 & 0.909 & 3.62 & $2.92(2.36)$ & $\begin{array}{l}0.08 \\
(0.1)\end{array}$ \\
\hline & No & $180(92.8)$ & $170(87.6)$ & -- & -- & -- & -- & -- \\
\hline \multirow[t]{2}{*}{ Birth control is the woman's business. } & Yes & $18(9.3)$ & $19(9.8)$ & 1.062 & 0.54 & 2.09 & 0.03 & 0.1 \\
\hline & No & $176(90.7)$ & $175(90.2)$ & -- & -- & -- & -- & -- \\
\hline \multirow{2}{*}{$\begin{array}{l}\text { Family size does not affect the well-being } \\
\text { of the family. }\end{array}$} & Yes & $28(14.4)$ & $59(30.4)$ & 2.59 & 1.56 & 4.3 & 14.24 & $0.00^{\star}$ \\
\hline & No & $166(85.6)$ & $135(69.6)$ & -- & -- & -- & $(13.3)$ & $(0.0)$ \\
\hline
\end{tabular}

Note ${ }^{\star}$ statistically significant $(\mathrm{p}<0.05)$. Yates' correction $\left(\mathrm{X}^{2}\right)$.

\section{Discussion}

There was a statistically significant difference between the socio-demographic distribution of urban and rural participants. The modal age of the participants was the same for both, while there were predominantly younger age groupsin the urban group (mean and age group distribution) than in the rural group. This is to be expected because the younger people tend to migrate to the urban areas in search of better economic well-being. Also, the finding of predominance of farming followed by manual occupation in the rural area in contrast with trading activities in urban area is probably due to availability of land and other farm resources and fewer employment opportunities in the rural areas of Nigeria. The study revealed a high level of knowledge about family planning among both groups which is consistent with findings by other researchers [19-23]. However, the urban group has greater percentage of people with the correct knowledge about family planning. This is to be expected because of the higher educational attainment in the urban group in contrast with those of the rural group. The difference in knowledge of the two main types of family planning among the two groups is comparatively not significant, while there is a significant difference between urban and rural respondents in terms of misconceptions about all artificial family planning methods causing infertility. Similarly, there is also a greater misconception about family planning being a sin, and only about preventing pregnancyin the rural population compared to urban area. The reason for this difference in misconception is probably due to the difference in educational attainment between the urban and rural populations studied. 
Ifeadike et al. Research Journal of Women's Health 2015,

Also, most respondents display more positive attitude in contrast with some other reports that mens' attitude to family planning is poor [23]. The positive attitude is shown by higher negative response to such questions as family planning being meant for wayward women, Family planning being a sin and women's business. Although, the findings show high negative response in both groups, there is comparatively a higher proportion in the urban group. The implication is that there is need for more health education and campaign in the rural areas. Recently, the campaign for family planning had been intensified especially with the collaboration of the Nigeria Governments through health institutions, primary health centres, international agencies and non-governmental agencies, with the result that awareness about the benefits of family planning has grown very much. Also, the traditional and cultural practices of having many children who would work in the farm is on the decline. People are probably seeing the need for a reduction in the size of the family in the face of rising economic hardship. However, the belief by the respondents that artificial methods of family planning cause permanent sterility, cancer raises concern on the correctness of the knowledge of the respondents particularly among the rural respondents where more than half $(50.5 \%)$ uphold such belief. Although this was reported by another researcher [24], it's a cause for concern since this will affect attitude and eventual use of such method if not checked.

The misconception that family planning is just about preventing pregnancy probablyresulted from the emphasis being placed on the control of the number of children to the near exclusion of other benefits of family planning. The use of family planning methods for other purposes such as prevention of sexually transmitted diseases is not emphasized much because some Christian denominations, especially Catholics believe that use of condom would encourage promiscuity. Such beliefs could result in men not approving of the use of family planning for themselves or for their spouses before reaching their desired number of children. The implication is that maternal and child mortality and morbidity would remain high or even rise higher.

Quite a reasonable number of the participants disagreed with the fact that only wayward women use contraception, although, more of the rural dwellers think otherwise when compared with their urban counterpart. This misconceptions could be the reason for the difference in the knowledge and attitude of rural men to family planning when compared to their urban counterparts. There is therefore a need to have more intensive enlightenment campaign to be targeted at the rural dwellers.

\section{Conclusion and recommendation}

Although, there is a high level of knowledge and positive attitude among men in both urban and rural populations studied, theurban men have a significantly higher level of knowledge and positive attitude than their rural counterpart.
Misconceptions about family planning is significantly high among the men, however, this is even higher in the rural population in contrast with the urban dwellers.

There is a need for agencies working in the area of family planning to increase awareness about birth control practices targeting men generally and especially those in the rural areas. Also good public enlightenment program (seminars, workshops and symposiums) should be used to correct the misconception that sterility or cancer result from artificial methods of family planning. There is need for further studies on men's practice of family planning.

\section{Competing interests}

The authors declare that they have no competing interests.

\section{Authors' contributions}

\begin{tabular}{|l|c|c|c|c|}
\hline Authors' contributions & COI & PNE & UMU & GAN \\
\hline Research concept and design & $\checkmark$ & $\checkmark$ & $\checkmark$ & -- \\
\hline Collection and/or assembly of data & $\checkmark$ & $\checkmark$ & $\checkmark$ & -- \\
\hline Data analysis and interpretation & $\checkmark$ & $\checkmark$ & $\checkmark$ & $\checkmark$ \\
\hline Writing the article & $\checkmark$ & $\checkmark$ & $\checkmark$ & $\checkmark$ \\
\hline Critical revision of the article & $\checkmark$ & -- & -- & $\checkmark$ \\
\hline Final approval of article & $\checkmark$ & $\checkmark$ & $\checkmark$ & $\checkmark$ \\
\hline Statistical analysis & $\checkmark$ & $\checkmark$ & -- & $\checkmark$ \\
\hline
\end{tabular}

\section{Acknowledgement}

We acknowledge the staff of Community Medicine Department for their efforts in the preparation of this study.

\section{Publication history}

Editor: Samir A. Farghaly, Cornell University, USA.

Received: 05-Sep-2015 Final Revised: 26-Oct-2015

Accepted: 02-Nov-2015 Published: 13-Nov-2015

\section{References}

1. World Health Organization. Health topics: family planning. WHO. 2013. I Website

2. Obionu CN. Primary Health Care for developing countries. Enugu. Delta publications. 2007; 249-250.

3. Mistik S, Nacar M, Mazicioglu M and Cetinkaya F. Married men's opinions and involvement regarding family planning in rural areas. Contraception. 2003; 67:133-7. | Article | PubMed

4. Trading Economics. Population growth (annual \%) in sub-Saharan Africa. World Bank indicators. 2012. I Website

5. United State Census Bureau. USCB world POP clock projection 2012. 2013. | Pdf

6. World population prospects. The $\mathbf{2 0 1 2}$ Revision-'low variant' and 'high variant' values. UN. 2012.

7. UN News Center. World population projected to reach 9.6 billion by 2050. UN report. 2013. | Website

8. World Population to surpass 7 billion in 2011. Explosive population growth means challenges for developing nations, Harvard school of Public Health. 2011. I Website

9. World Population Clock. 7 Billion people (2013)-worldometers. 2013. | Website

10. Advanced family planning 2011. AfriComNet. 2013.

11. Kofoworola $\mathrm{AO}$ and Bose El. Promoting male participation in family planning in rural Nigeria: A community-based intervention. International conference on family planning. Dakar,Senegal. 2011. | Website 
Ifeadike et al. Research Journal of Women's Health 2015,

12. Oyediran KA, Ishola GP and Feyisetan BJ. Factors affecting ever-married men's contraceptive knowledge and use in Nigeria. J Biosoc Sci. 2002; 34:497-510. | Article | PubMed

13. Mason $K$ and Lynnam P. Not for women only: child-spacing clubs for Malawian men. In: Male involvement in family planning decisionmaking in Ile-Ife.Osun state, Nigeria. Afr J Reprod Health. 2010; 14:4546.

14. Osede OI, Uwaifoh A, Anthony ON, Charity UO, Harrison OO and Okhiai O. Contraceptive choice among married men in Ekpoma. African Journal of Biomedical Research. 2011; 14:13-14. | Article

15. Gbolahan $A O$ and James $M$. Family planning knowledge, attitudes and practices of males in Ilorin, Nigeria. International family planning perspectives. 1991; 17:21-22. | Article

16. Bustamante-Forest $R$ and Giarratano G. Changing men's involvement in reproductive health and family planning. Nurs Clin North Am. 2004; 39:301-18. | Article | PubMed

17. OnitshaNorth. | Website

18. Ayamelum. | Website

19. NPC/ICF. Nigeria Demographic and Health Survey 2008. Abuja, Nigeria: National Population Commission and ICF macro. 2009. I Website

20. Lawoyin TO, Osinowo H, Babatunde M, Bajomo TG, Betiku AO, Biakolo, Busari KT and Fehintola A. Family planning in rural Nigeria: a study among men. Afr J Med Med Sci. 2002; 31:159-62. | Article | PubMed

21. Orji EO and Onwudiegwu U. Prevalence and determinants of contraceptive practice in a defined Nigerian population. $J$ Obstet Gynaecol. 2002; 22:540-3. | Article | PubMed

22. Duze MC and Mohammed IZ. Male knowledge, attitudes, and family planning practices in northern Nigeria. Afr J Reprod Health. 2006; 10:5365. | Article | PubMed

23. Uwaifo A, Anthony ON, Harrison OO, Charity UO, Williams AA and Okhial $O$ et al. Comparative study on the awareness of contraceptive methods amongst married males population of Ekpoma, Nigeria. African Journal of Biomedical research. 2011; 14:3-4. | Article

24. Ozumba CO. Family planning among married men: a pilot study in Abakpa Nike Enugu state Nigeria. Sixth African Population Conference. 2011. | Website

\section{Citation:}

Ifeadike CO, Eze PN, Ugwoke UM and Nnaji GA. Comparative assessment of family planning knowledge and attitude of men in urban and rural areas of Anambra state, South-East of Nigeria. Res $J$ Womens Health. 2015; 2:3.

http://dx.doi.org/10.7243/2054-9865-2-3 